\title{
Reducing Student's English Dialogue Anxiety in Online Learning through Board Game
}

\author{
Rahma Nuzulia ${ }^{1 *}$ \\ Catur Kepirianto ${ }^{2}$ \\ Diponegoro University, \\ Jl. Prof. Sudarto No.13, Tembalang, Kec. Tembalang, Kota Semarang, Jawa \\ Tengah 50275 \\ *rahmazainal27@gmail.com
}

Article history: Submitted on $18^{\text {th }}$ November 2020; Accepted on $30^{\text {th }}$ December 2020; Published on $31^{\text {th }}$ December 2020

\begin{abstract}
The COVID 19 has been going on since April 2020 in Indonesia. It has resulted in the Indonesian government, especially the Ministry of Education and Culture, taking preventive steps to minimize contracting the virus. One of them is using online learning for students to go to school. However, there are challenges for teachers and students while learning in an online class. It also happens in an English lesson, especially a dialogue activity. This research aims to prove whether using a board game can be effective media to reduce students' language anxiety level or not during English learning in an online classroom. The kind of board game is the combination between snake and ladder and candy land, or it has been modified based on learning purpose. The research design used in this research is a quasi-trial non-equivalent control group design. The samples of this research are 60 ninth grades of junior high school students which are divided into the trial and control group. Data analyses used in this research are using SPSS mean score, data deviation, while hypothesis testing used in this research is the Mann-Whitney test. The result showed that a board game can reduce students' anxiety levels. The data showed that the mean score of students after implementing board game reduces by 2.90 points, while the standard deviation increases by 2.901 points. From the Mann-Whitney test, it is known that Asymp. Sig. (2-tailed) is 0.003 or $<0.05$ which shows that $\mathrm{H} 0$ is rejected, and $\mathrm{H} 1$ is accepted. From the data analysis, it can be shown that the board game is effective media to reduce students' language anxiety in dialogue activity during learning in an online class.
\end{abstract}

Keywords: board game, language anxiety, online learning 


\begin{abstract}
ABSTRAK
Wabah corona telah berlangsung sejak bulan April 2020 di Indonesia. Hal ini mengakibatkan pemerintah Indonesia khususnya kemendikbud mengambil langkahlangkah pencegahan guna meminimalisir terjangkit virus tersebut. Salah satunya dengan belajar online bagi siswa. Namun terdapat tantangan yang dikelubkan pendidik dan anak didik selama belajar melalui kelas online, seperti siswa yang sering absen, siswa akan cepat merasa bosan, siswa cenderung pasif dalam proses pembelajaran, siswa kurang menguasai materi pembelajaran, dan masib banyak lagi. . Hal ini juga terjadi dalam pelajaran bahasa Inggris, khususnya kegiatan berbicara. Penelitian ini bertujuan untuk membuktikan apakah penggunaan board game dapat menjadi media yang efektif untuk. mengurangi tingkat kecemasan berbahasa siswa selama pembelajaran bahasa Inggris di kelas online. Jenis permainan papan tersebut merupakan gabungan antara ular tangga dan tanah permen, atau telah dimodifikasi berdasarkan tujuan pembelajaran. Rancangan yang digunakan menggunakan pendekatan penelitian percobaan semi dengan ketidakequivalen kelompok pembanding. Sampel kajian ini adalab 60 siswa SMP kelas IX dibagi kedalam grup ujicoba dan grup pembanding. SPSS 24 dimanfaatkan sebagai alat analisis dengan melibat rata-rata skor, penyimpangan data, sedangkan pengujian hipotesis adalah uji Mann-Whitney. Data menunjukkan bahwa nilai rata-rata siswa setelah penerapan permainan papan berkurang 2,90 poin, sedangkan standar deviasi meningkat 2,901 poin. Dari uji Mann-whitney diketahui bahwa Asymp. Sig. (2-tailed) adalah 0,003 atau <0,05 yang menunjukkan bahwa $\mathrm{HO}$ ditolak dan $\mathrm{H} 1$ diterima. Dari hasil analisis data dapat diketahui bahwa board game merupakan media yang efektif untuk mengurangi kecemasan berbahasa siswa dalam aktivitas berbicara selama pembelajaran di kelas online.
\end{abstract}

Kata kunci: Papan Permainan, Kecemasan Berbahasa, Pembelajaran Daring

\title{
INTRODUCTION
}

The corona virus has been going on since April 2020 in Indonesia. This has resulted in the Indonesian government, especially the Ministry of Education and Culture, taking preventive steps to minimize contracting the virus. These steps include washing hands, using masks, keeping your distance, not shaking hands, and prohibiting gathering activities, and avoiding crowds. These preventive measures have an impact on all sectors, including the education sector. The government or the ministry of education and culture has determined that all levels of education must research from home. To continue to carry out the learning and teaching process between teachers and students even at home, the government offers to use online learning applications that are currently widely used. According to Bartley \& Golek, 2004 as cited in (Nguyen, 2015), online learning is a distance learning which 
possibly facilitates students to engage with teachers. During pandemic situation, there are changes in learning and teaching from conventional classrooms to distance classes during a pandemic like today, which is a challenge for both teachers and students. The need for signals, quotas, and devices to learn is a challenge in the online learning process. Moreover, there are other challenges, including teacher supervision of students, student interest and motivation, the courage of students to express opinions, learning activities that require discussion or group work, management of learning time, and appropriate teaching approaches and methods. If the above challenges cannot be fixed properly, they will likely cause problems in online learning, such as students who do not submit assignments on time, students who are often absent, students will quickly feel bored, students tend to be passive in the learning process, students do not master the learning material as a whole, and much more. As a consequence, these will have impacts on the students' achievement which are related to the competencies and indicators of each subject, including in English.

In learning English, especially dialogue, students generally have difficulty dialogue individually and dialogue in public because dialogue is a production skill in which students must convey ideas and emotions to respond to their interlocutors. It is difficult if the students do not have good English skills, and the students who have shy or passive personality, although they have capable enough. During the pandemic, the use of online learning also adds to the difficulty of teachers in carrying out dialogue lessons. Their students are more become passive or embarrassed to speak English individually. Besides, the teacher cannot create groups while using an online platform, so the students cannot make short conversation activities or roleplay activities as they do in the class. The problem of students who tend to be passive, afraid, nervous to speak English individually in online learning adds to the difficulty of learning dialogue during the pandemic situation. This case happens in SMP Negeri 5 Tanjungpinang. The levels of students' language anxiety when they try to speak English are generally at a high and medium level. Of the 30 students in one class, there are 21 students at a medium level, 2 students at a high level, and 7 students at a low level. Various kinds of reactions or anxiety symptoms arise, both physically such as heart racing, feeling weak, trembling, fidgeting, and behaviorally such as unmotivated to come to an online class, just silent, slow response, or wasting time). Alphert and Harber cited in (Mustapha Hajebi, 2017) divided language anxiety into two types which are facilitating and debilitating anxiety:

1. Facilitating anxiety encourages the students to be motivated and challenged in a positive way of doing the task. For example, the 
students have good competition in improving themselves to master language.

2. Debilitating anxiety reduces student's confidence, and increasing student's worry while researching the language. For example, the students feel uncomfortable and try to avoid themselves from the language learning

Furthermore, the learning process based on the competencies and indicators that have been determined in the 2013 curriculum must still be carried out even through the use of online media. One example of competence is that students can create conversational texts both spoken and written that include interpersonal interactions such as expressing hopes and congratulations on achievement or joy based on the context. To carry out the competencies to be achieved and to overcome students' language anxiety problems, a teacher needs to find appropriate strategies to overcome anxiety in the classroom. It seems that anxiety tends to have negative impacts on acquiring and producing language. According to Gardner (1989) explained that anxiety has an impact that is reducing in the learning process and language production itself. This is shown by research conducted by Azizifar \& Fariadian (2015) reveals the effects of uneasiness of having conversation with peers are mental issues, low inspiration, concentration, and accomplishment adversely, and resulting mistakes in language learning. Besides, it affects learners' self-esteem, and their active awareness in the session.

Ochs (1991) in (Fadlan, 2017) may divided the indications of anxiety that which will be happened into: a) voice such as tremble, as well moderate, as well quick, dull, un-emphatic, and raspy, b) verbal impact such as stammers ending or ungainly delays, the chase of words, rehashed the same word, c) mouth and throat such as well gradually over and over, and breathes intensely, d) facial expressions such as no eye contact, roll eye, frowns as well regularly, the confront muscle is tense, e) arms and hands such as unbending or tense, wriggle, motionless, sweat, f) body movement such as body swap too often and paces \& shuffles feet. Furthermore, some indication can be watched, and few of them cannot be seen and analyzed accurately.

The use of games in dialogue learning is trusted to reduce students' anxiety pressure when online learning, while at the same time achieving learning objectives based on predetermined competencies and indicators. Saefullah, Romly \& Abdullah (2019), cited in (Sofyan et al., 2019) explained that playing games in English dialogue invite students to speak in English and improve their English dialogue skills. Furthermore, Von Ann (2006) cited in Fakhrurrazy (2018) added that the use of games in learning is a fun activity through rules. Moreover, Savignon (1976) cited in (Owen et al., 2019), explains the benefits of using games and discussions in learning, namely that 
it can arouse students' emotional interest and attract students' attention to authentic interactions in the classroom.

The use of games in English dialogue learning has been carried out by several previous researchers, including (Riandi \& Suryani, 2018) who applied the effectiveness of Kim's memory game to improve dialogue skills. The results revealed that the game able to increase their dialogue skills. Then, Fakhrurrazy has also proven that the use of communication games on the dialogue skills of students at SMP PGAI Padang is better. (Fakhrurrazy, 2018). Also, Owen et al. (2019) researched the effects of using language games and information gap activities on students' dialogue performances. The research has implemented on 124 respondents consisting of 4 experiment classes and one control class. The language games used by researchers are board games, guessing games, passing on information, describing, and drawing. The results of this research indicate that there is an increase in the students' dialogue score or posttest after implementing learning based on the communicative language teaching approach using language games. Then, Pinandhita (2013) also used a game in teaching dialogue called the riddle game. This game allows students to practice dialogue English in a variety of ways. Qualitative applied in collecting data about what are the strengths and the weaknesses of using riddle games in dialogue class 8 MTSn Kedungdalar. The results show that riddle games can increase students' interest in dialogue, make students happy in learning narrative text, increases student vocabulary, and make students active in learning, while the drawback is to make the class noisy.

Of the many choices of games for learning English, the writer chooses one of the games that can be applied in learning dialogue during online learning in this pandemic, namely board game. The reason the researchers chose board game is that besides it can be used as a medium for reaching indicators taught in dialogue, this game is also a type of game where the tools or parts of the game can be easily moved or the game is too easy or not too complicated to be used as a learning tool for students of online learning. Since nowadays, games like this are rarely played by $\mathrm{Z}$ generation, so this game is considered quite appropriate, easy, and challenging for them to play. Another reason why researchers choose board games during online learning is that this media can train students' language skills where they can interact or socialize in a fun way and unconsciously practice their language with the help of media such as zoom application. This is in accordance with what Indriana said in Arfani \& Sulistia (2019), the selection of media or games must be in accordance with the learning objectives to be achieved and provide training and good character building such as cooperation, honesty, discipline in learning. In addition, researchers also agree with what was conveyed by Lely Tobing in Ainurrohmah (2019) which states that the use of a board game is a medium or media that contains three aspects, namely visual or image, 
audio or discussion, and affective or attitude. And last but not least, board game is an effective tool to encourage or motivate students to learn, especially to speak English.

According to Fathnan in Taka (2019), some benefits of snake and ladder board games are: (1). Provide knowledge to children through the learning process of playing while learning. (2). Stimulates developing thinking, creativity, and language to be able to foster attitude, mentality, and morals. (3). Creating an attractive playing environment, providing a sense of security and sun. (4). Know losing and winning (5). Encourage students with cooperative and patient learning. Then, some benefits of using board games for learners (1). Provide meaningful learning opportunities. (2). Improve the learning ways (3). Connect to real-life situations (4). Encore the use of authentic materials (5). Guarantee fresh content. While according to Radila in Taka (2019), there are some benefits for the teacher; (1). Helping teachers get learners involved (2). Get a more positive and proactive response (3). Enhance students' motivation (4). Provide endless possibilities and kinds of material (5). Improve teacher's teaching practice (6). Encourage teachers to put aside the textbook and usual teaching practices temporarily

In the case of using board games in learning English dialogue, then there some previous studies have been researched about using board games. Cheng (2018) had been proof that the board games she applied such as Codenames ${ }^{\circledR}$ and Dixit ${ }^{\circledR}$, Apples to Apples can affect students' language anxiety. She used a communicative approach and task-based instruction in implementing the board games. The result showed that ESL students become more relaxed, and they are more focused on playing the game rather than dialogue English. Besides, the students' performances, such as accuracy, fluency, and pronunciation, are increased after playing the board games for four weeks. Based on the pretest and posttest results, 84 percent of participants increased their oral performance. It has supported by the judges of native English speakers, which explained students have positive differences in the posttest.

Arfani \& Sulistia (2019) and Ratih \& Ningsih (2017) did qualitative research on the implementation of the "snake and ladder" board game in teaching dialogue. This research is purposed to find out the strengths and weaknesses of using media board game. The result showed that the strengths of using the board game are fun, easy, effective, and motivated media for the students to practice in English dialogue. Furthermore, the disstrengths of using a media board game are preparing the equipment of the media board game, managing time wisely, and feeling difficult to control the students' mistakes while practicing in communications.

Another similar finding is found by Zuhri \& Kusyairi (2020). They did classroom action research to investigate the use of board games in order to upgrade learners' oral competency in MTs Nahdlatun Nasyiin Kadur 
Pamekasan. The aim of this research is to describing the implementation of board games in dialogue class, and describing the increase of students' dialogue ability through board games. The result showed that using board games able to make students enthusiastic to speak English, and it can improve students' dialogue skills.

Ainurrohmah (2019) did research on the advance of the tool board game for teaching greeting and introduction for seventh-grade students of SMP Dewantara Surabaya. This research aims to examine the development of the media board games in teaching greeting and introduction. The result showed mean of the posttest result is increased by 85.32 rather than the mean of the pretest by 56.17 . It showed the development of board games used in this research is more effective to improve students' ability in teaching greetings and introductions.

The gap and the significance of this research are there has been no research on the use of a board game during online learning to reduce students' dialogue anxiety. Hence, this research aims to prove whether or not a board game able to reduce dialogue anxiety levels during online learning in a pandemic situation. Thus, the formulations of the questions in the research such as: 1) What are the symptoms of student anxiety identified in dialogue English in online learning, 2) Is the board game able to reduce student's dialogue anxiety in online learning? Besides, the research hypothesis also included in this research is: 1) $\mathrm{H}_{0}$ means there is no significant difference in using a board game toward students' language anxiety in online learning. 2) $\mathrm{H}_{1}$ means there is a significant difference between using board games toward student's language anxiety in online learning.

In this research, the form of a board game follows candy land while the game's instructions follow a dice consisting of 1 to 6 in which players move counters along with a series of squares according to throws of dice. Through this game, the students try to make English conversations when they stop at the color boxes. Each player starts with a piece in the first box and takes turns throwing the dice. The pointer counts according to the number of dice that has thrown by the player. 
Picture 1:

A modified board game

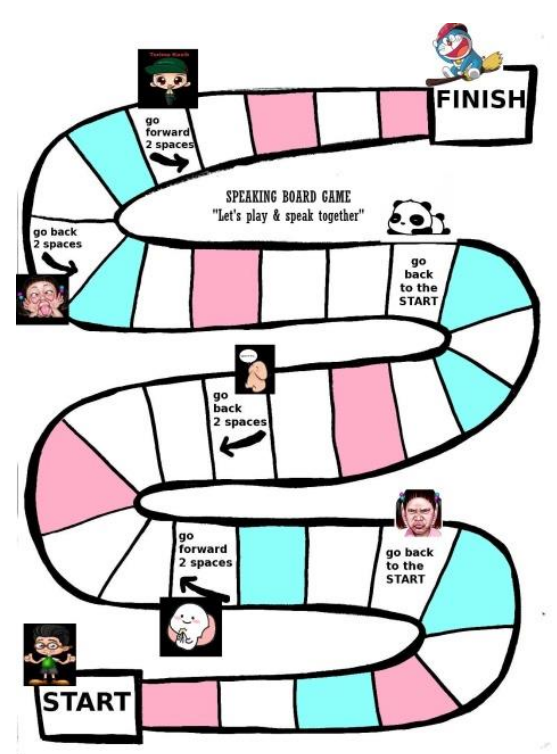

\section{METHOD}

Researchers use a quasi-trial research design because this research used treatment, namely board game to prove whether board game was able to reduce students' dialogue anxiety in online classes or not. The research subjects are 60 ninth-grade students of junior high school dividing into 30 students in the trial group and 30 students in the control group. The research location is at SMP Negeri 5 Tanjungpinang. The treatments are six times, including pretest and posttest in the trial group, while the control group does not receive any treatment at all. Before experimenting, the two groups (trial and control) received a pretest to determine their level of anxiety, treatments are given in the trial group, and ended with a posttest to find out whether the board game affected student anxiety in this case reducing student's dialogue anxiety. For more details, the following shows a quantitative research method with a quasi-trial design with a non-equivalent control group design. 
Table 1 :

Non-equivalent Control Group Design

\begin{tabular}{|l|l|l|l|}
\hline Group & Pretest & Treatment & Posttest \\
\hline TG & $\mathbf{A}_{1}$ & $\mathbf{T}_{1}$ & $\mathbf{A}_{2}$ \\
\hline CG & $\mathbf{A}_{3}$ & $\mathbf{T}_{2}$ & $\mathbf{A}_{4}$ \\
\hline Note: & TG $\quad=$ Trial group \\
& CG $\quad=$ Control group \\
& $\mathrm{T}_{1} \quad=$ Learning using board game, \\
& $\mathrm{T}_{2} \quad=$ Learning without using board game, \\
$\mathrm{A}_{1}$ and $\mathrm{A}_{3}=$ students' anxiety level before giving the treatment, \\
$\mathrm{A}_{2}$ and $\mathrm{A}_{4}=$ students' anxiety level after giving the treatment.
\end{tabular}

Through observation, the researcher uses note-taking technique on the students' behavior to investigate their anxiety symptoms while dialogue English in online learning. Moreover, the researcher becomes an active observer who follows the learning process in this research as a teacher. Then, eight students are interviewed related to their feelings while dialogue English in online learning. The researcher also uses semi-structured interview to find out the data about students' feelings while dialogue English in online learning. According to Sugiyono (2015), the semi-structured interview is also called an in-depth interview which the questions used in this interview is more flexible because of finding ideas or opinion of respondents. While interviewing, the researcher has to concentrate on what respondents are saying, and they need to are recorded. Moreover, the survey used in this research is the Public Dialogue Classroom Anxiety Scale (PSCAS), which was implemented and developed by Yaikhong \& Usaha (2012). The PSCAS divided into seventeen stuffs with optimistic and pessimistic statements which are related to students' feeling while dialogue. It was planned on a 5 point Likert scale extending from "Strongly Disagree" to "Strongly Agree" with values 1-5 allotted to them individually. Hence, the complete duplicate totals of a PSCAS are 85 and after that deducted by 17 . Totals $68-85$ are considered as extreme anxiety, 51-68 are categorized as fair anxiety, and 17-51 are categorized as soft anxiety.

In analyzing the data, researcher also refers to Sugiyono (2015) explains that data analysis in qualitative data conducted interactively and an ongoing process in getting redundant data. There are three parts in examining data, which are data reduction, data display, and conclusion verification. While in quantitative data, the researcher will compare the total of the students' scores before and after the treatment. If the students' post-test score 
results are lower than students' pre-test scores, then the treatment is efficient to reduce students' language anxiety levels. Moreover, the researcher calculates the mean score and standard deviation of the students' answers. Both pre-test and post-test use the Statistical Product and Service Solution (SPSS 24) Analysis. To examine of hypothesis, data analysis used in this research is a non-parametric test using the Mann-Whitney test through SPSS version 24. In this research, the independent variable is a board game, and the dependent is students' dialogue anxiety level.

\section{FINDINGS AND DISCUSSION}

As previously explained, A purpose in this research is to find out what anxiety symptoms students experience when learning English in an online class, especially dialogue, and whether the usage of board games can reduce students' dialogue anxiety or not. Since anxious feeling is one of the common problems faced by students when learning a foreign language, especially dialogue and learning English during the pandemic through online learning, this research needs to be implemented. Based on observations, questionnaires, and interviews as research instruments, this research resulted in the following findings:

\section{Student's anxiety symptoms when dialogue English in online learning}

Before the researcher finds out the effectiveness of a board game to reduce students' English dialogue anxiety in online learning, the researcher explores the student's anxiety symptoms identified in dialogue and learning English during the pandemic through online learning. There are two kinds of symptoms which are called behavioral symptoms and physical symptoms. The following explanations are described below.

\section{a. Behavioral symptom}

Before giving the treatment, the students are allowed to do dialogue practice in an online classroom with peers. The result showed that most of the students were reluctant or avoided having conversations in English. These indicated that they did not respond to the teacher's instruction to have conversations in English. Besides, the signs that appear are they did not dare to convey their ideas when dialogue English or keep quiet. When they speak English, their faces looked tense and afraid if they made errors in conversations with their friends. Besides that, when it discovered that next week is the practice of dialogue English, they avoided the class or were absent 
on that day (not motivated), often being late or wasting time when asked to write English conversation scripts.

b. Physical symptom

Besides behavioral symptoms, the researcher also interviewed four students who seemed anxious. The researcher identified physical symptoms such as blushing, trembling, and heart racing. For further information, the data which were gathered or summarized are included in the table 1 below.

Table 2:

Students' language anxiety symptoms in dialogue practice in online learning

\begin{tabular}{|c|c|c|}
\hline Students' reactions & $\begin{array}{l}\text { Behavioral } \\
\text { symptom }\end{array}$ & $\begin{array}{l}\text { Physical } \\
\text { Symptom }\end{array}$ \\
\hline $\begin{array}{l}\text { feeling nervous if they should speak } \\
\text { English alone in online learning }\end{array}$ & $\begin{array}{l}\text { Behavioral } \\
\text { symptom }\end{array}$ & \\
\hline heart racing & & $\begin{array}{l}\text { Physical } \\
\text { Symptom }\end{array}$ \\
\hline feeling weak & & $\begin{array}{l}\text { Physical } \\
\text { Symptom }\end{array}$ \\
\hline nervous and afraid & $\begin{array}{l}\text { Behavioral } \\
\text { symptom }\end{array}$ & \\
\hline bringing a book & $\begin{array}{l}\text { Behavioral } \\
\text { symptom }\end{array}$ & \\
\hline body is trembling & & $\begin{array}{l}\text { Physical } \\
\text { Symptom }\end{array}$ \\
\hline $\begin{array}{l}\text { the lip is trembling, and the } \\
\text { pronunciation is not clear }\end{array}$ & & $\begin{array}{l}\text { Physical } \\
\text { Symptom }\end{array}$ \\
\hline $\begin{array}{l}\text { waste time and don't want to come to } \\
\text { the class }\end{array}$ & $\begin{array}{l}\text { Behavioral } \\
\text { symptom }\end{array}$ & \\
\hline $\begin{array}{l}\text { There is a word } e h m \text {... ehmm, not fluent } \\
\text { (stammering) }\end{array}$ & $\begin{array}{l}\text { Behavioral } \\
\text { symptom }\end{array}$ & \\
\hline
\end{tabular}




\begin{tabular}{|l|l|l|}
\hline forget everything & $\begin{array}{l}\text { Behavioral } \\
\text { symptom }\end{array}$ & \\
\hline $\begin{array}{l}\text { Shaking their bodies and legs, and } \\
\text { their hands put behind their backs or } \\
\text { they are fidgeting }\end{array}$ & $\begin{array}{l}\text { Physical } \\
\text { Symptom }\end{array}$ \\
\hline Speak so fast and low voice & $\begin{array}{l}\text { Behavioral } \\
\text { symptom }\end{array}$ & \\
\hline personality factor (embarrassed) & $\begin{array}{l}\text { Behavioral } \\
\text { symptom }\end{array}$ & \\
\hline Unconfident & $\begin{array}{l}\text { Behavioral } \\
\text { symptom }\end{array}$ & \\
\hline
\end{tabular}

From the data above, it has been shown that the students tend to have behavioral symptoms rather than physical symptoms. It is in line with what has been studied by Sanaei (2016) research about English Foreign Learners' symptoms and their reaction in doing oral narrative in the classroom. Some of the symptoms can be watched, and some of the symptoms cannot be seen and analyzed accurately. Also, through this online class, the researcher was easier to identify the behavioral symptoms. Furthermore, it is in line with Ochs (1991) in Fadlan (2017) which also divided the indications of anxiety that which will be happened into: a) voice such as tremble, as well moderate, as well quick, dull, un-emphatic, and raspy, b) verbal impact such as stammers ending or ungainly delays, the chase of words, rehashed the same word, c) mouth and throat such as well gradually over and over, and breathes intensely, d) facial expressions such as no eye contact, roll eye, frowns as well regularly, the confront muscle is tense, e) arms and hands such as unbending or tense, wriggle, motionless, sweat, f) body movement such as body swap too often and paces \& shuffles feet. Furthermore, some indication can be watched, and few of them cannot be seen and analyzed accurately.

\section{The using of board game to reduce students' dialogue anxiety in online learning}

There are two parts of explanations researcher covered in this part. First, is a board game able to reduce students' language anxiety level in 
dialogue through an online class or not, and secondly, the hypothesis testing using Mann Whitney test of students' dialogue anxiety score.

a. Is a board game able to reduce students' language anxiety level in English dialogue through an online class?

Before giving treatment, the researcher gives students pre-test or questionnaire to determine or calculate their dialogue anxiety level in online learning

Table 3:

The distribution of frequency and percentage of class in pre-test

\begin{tabular}{|l|l|l|l|l|l|l|l|}
\hline \multirow{2}{*}{ Group } & \multicolumn{7}{|c|}{ Dialogue Anxiety Level } \\
\cline { 2 - 8 } & $\begin{array}{l}\text { Sample } \\
\mathbf{( N )}\end{array}$ & $\begin{array}{l}\text { Soft } \\
\mathbf{( 1 7 -} \\
\mathbf{5 0 )}\end{array}$ & $\begin{array}{l}\text { Percentage } \\
\mathbf{( \% )}\end{array}$ & $\begin{array}{l}\text { Fair } \\
\mathbf{( 5 1 - 6 8 )}\end{array}$ & $\begin{array}{l}\text { Percentage } \\
\mathbf{( \% )}\end{array}$ & $\begin{array}{l}\text { Extreme } \\
\mathbf{( 6 9 - 8 5 )}\end{array}$ & $\begin{array}{l}\text { Percentage } \\
\mathbf{( \% )}\end{array}$ \\
\hline Trial & 30 & 7 & $23.33 \%$ & 21 & $70 \%$ & 2 & $6.66 \%$ \\
\hline Control & 30 & 10 & $33.33 \%$ & 15 & $50 \%$ & 5 & $16.67 \%$ \\
\hline
\end{tabular}

The result is in table 3 above, in the trial group, there are 21 students $(70 \%)$ have moderate dialogue anxiety level, 7 students $(23.33 \%)$ have low dialogue anxiety level, and two students $(6.66 \%)$ have high anxiety level. It showed that students mostly have moderate anxiety while practicing short dialogue conversations in the classroom. Meanwhile, in the control class, there are 15 students $(50 \%)$ have moderate anxiety level, 10 students $(33.33$ $\%)$ have low anxiety level, and five students $(16.67 \%)$ have high anxiety level. It showed that in the control class, more students have high anxious rather than in the trial class. Moreover, more students have moderate anxiety rather than in the control class. Therefore, these findings indicated that there are three levels of anxiety faced by the students from both groups (trial and control) while practicing short dialogue conversation. 
Table 4:

The distribution of frequency and percentage of class in posttest

\begin{tabular}{|l|l|l|l|l|l|l|l|}
\hline \multirow{2}{*}{ Group } & \multicolumn{7}{|c|}{ Dialogue Anxiety Level } \\
\cline { 2 - 8 } & $\begin{array}{l}\text { Sample } \\
\mathbf{( N )}\end{array}$ & $\begin{array}{l}\text { Soft } \\
\mathbf{( 1 7 -} \\
\mathbf{5 0}\end{array}$ & $\begin{array}{l}\text { Percentage } \\
\mathbf{( \% )}\end{array}$ & $\begin{array}{l}\text { Fair } \\
\mathbf{( 5 1 - 6 8 )}\end{array}$ & $\begin{array}{l}\text { Percentage } \\
\mathbf{0 \% )}\end{array}$ & $\begin{array}{l}\text { Extreme } \\
\mathbf{( 6 9 - 8 5 )}\end{array}$ & $\begin{array}{l}\text { Percentage } \\
\mathbf{( \% )}\end{array}$ \\
\hline Trial & 30 & 11 & $36.66 \%$ & 17 & $56.66 \%$ & 2 & $6.66 \%$ \\
\hline Control & 30 & 6 & $20 \%$ & 20 & $66.67 \%$ & 4 & $13.33 \%$ \\
\hline
\end{tabular}

After giving the treatment or doing the experiment for six meetings, the comparison of the result can be explained through table 4 above. In the trial group, most students are at moderate levels. There are 11 students $(36.66 \%)$ who have low levels of anxiety, 17 students $(56.66 \%)$ have moderate levels of anxiety, and two students $(6.66 \%)$ have high levels of anxiety. Meanwhile, after six meetings in control class, the result of the post-test questionnaire that is presented in table 3.3 above showed that there 20 students $(66.67 \%)$ have moderate anxiety level, 6 students $(20 \%)$ have low anxiety level, and 4 students $(13.33 \%)$ have high anxiety level. So, in the trial class, there was a noteworthy dissimilarity between pre-test or before giving treatments and post-test or after giving treatment. Therefore, it able to be summarize that the use of a board game can reduce students' language anxiety levels.

Table 5:

Mean score and standard deviation of students' language anxiety level in the pre-test and post-test

\begin{tabular}{|l|l|l|l|l|}
\hline Test & $\mathbf{N}$ & Class & Mean & $\begin{array}{l}\text { Standard } \\
\text { Deviation }\end{array}$ \\
\hline Pre-test & 30 & Trial & 53.70 & 9.480 \\
\hline Pre-test & 30 & Control & 57.30 & 11.284 \\
\hline Post-test & 30 & Trial & 50.80 & 11.571 \\
\hline Post-test & 30 & Control & 58.23 & 10.871 \\
\hline
\end{tabular}

Based on table 5 above, it shows the mean score between the trial and control class in the pretest and the post-test. In the pretest and post-test results, the mean scores of the trial class are lower than the control class, so it indicated 
that the students' dialogue anxiety level in the control class is higher than the trial class. Besides, there was a noteworthy dissimilarity between pre-test and post-test in the trial class, the result showed that the mean score of students after implementing a board game reduces by 2.90 points. Meanwhile, in the control class, the result showed that the mean score of learners increases in 0.93 points.

Moreover, the standard deviation of both groups is dissimilar. Standard deviation is central function in descriptive analysis which collects sum of variety of the students' total. The higher standard deviation implies is that the more fluctuation the score was and the lower standard deviation implies that the more comparable all the score was. From the table, in the trial class, the standard deviation increases 2.901 points. It proved that the use of a board game was better to be implemented in online learning to reduce students' language anxiety.

\section{b. Hypothesis testing using Mann Whitney test of learners' dialogue anxiety score}

Hypothesis testing uses Mann Whitney Test through SPSS to verify the hypothesis of the study. In order to prove is there any significant difference between using board games toward student's language anxiety in online learning or not, so statistical analysis was engaged. The result of Mann Whitney test can be observed in the below:

Table 6:

Man Whitney test result of trial class

\begin{tabular}{|l|l|}
\hline \multicolumn{2}{|l|}{ Test Statistics $^{\mathbf{a}}$} \\
\hline & $\begin{array}{l}\text { Student's } \\
\text { dialogue } \\
\text { anxiety scor e }\end{array}$ \\
\hline Mann-Whitney U & 250.500 \\
\hline Wilcoxon W & 715.500 \\
\hline Z & -2.952 \\
\hline $\begin{array}{l}\text { Asymp. Sig. (2- } \\
\text { tailed) }\end{array}$ & .003 \\
\hline a. Grouping Variable: Media \\
\hline
\end{tabular}


Based on table 6 above, it is known that Asymp. Sig. (2-tailed) is 0.003 or $<0.05$ which shows that $\mathrm{H} 0$ is rejected, and $\mathrm{H} 1$ is accepted. As a consequence, the result of the test showed that there is a noteworthy dissimilar in using dialogue board game toward students' language anxiety in practicing short dialogue conversation in online learning. It relates to what has been researched by Cheng (2018) that board games make learners become more focused on playing the game rather than using only dialogue English. Besides, the students' performances, such as accuracy, fluency, and pronunciation, are increased after playing the board games for four weeks. Based on the pretest and posttest results, 84 percent of participants increased their oral performance. It has supported by the judges of native English speakers, which explained students have positive differences in the posttest. For instance, the result of using a game or board game for English as a second language (ESL) is that the students are not being anxious while having an English conversation.

\section{CONCLUSION}

From this research, the researcher can identify some students' dialogue symptoms like physical and behavioral symptoms. While practicing dialogue in online learning, students tend to have behavioral symptoms such as looked tense and afraid, did not dare to convey their ideas, did not respond to the teacher's instruction. Furthermore, the use of a board game can reduce students' dialogue anxiety in online learning. It has shown that there is a significant difference before and after implementing a board game in English subjects in online learning. The data show that there is a decrease in students' dialogue anxiety levels after using a board game. Through this research, the researcher hopes that modified board games in this research will be beneficial media to those teachers who want to do dialogue activities in online learning. However, this research did not cover the strengths and disstrengths of using a modified board game in online learning, so the researcher suggests for future researchers to research it.

\section{REFERENCES}

Ainurrohmah, D. A. (2019). Pengembangan Media Board Game Pada Mata Pelajaran Bahasa Inggris Materi Pokok Greeting and Introduction Kelas Vii Di Smp Dewantara Surabaya.

Arfani, S., \& Sulistia, A. (2019). Teaching Speaking Using a "Snake and Ladder" Board Game: a Teacher Story. Research and Innovation in Language Learning, 2(1), 65. https://doi.org/10.33603/rill.v2i1.1642

Azizifar, A., \& Fariadian, E. (2015). The Effect of Anxiety on Iranian EFL 
Learners Speaking Skill. International Journal of English Language and Linguistics Research Vol.3, 3(7), 19-30.

Cheng, Y. (2018). The Effect Of Using Board Games In Reducing Language Anxiety And Improving Oral Performance.

Fadlan, A. (2017). Factors Causing Language Anxiety of EFL Student in Classroom Presentation.State University of Makasar:

Fakhrurrazy, R. (2018). The Effect of Communication Games and SelfEsteem towards Students' Speaking Skill. Al-Ta Lim Journal, 25(2), 163 170. https://doi.org/10.15548/jt.v25i2.398

Gardner, R. C. (1989). Anxiety and Second-Language Learning: Toward a Theoretical Clarification *.

Mustapha Hajebi. (2017). The Effects of Anxiety on Iranian EFL Learners Performance through Pre and Post-Test on Case Study. International Journal of Case Studies, 6(2017-10), 41-50. http://www.casestudiesjournal.com

Nguyen, T. (2015). The Effectiveness of Online Learning: Beyond No Significant Difference and Future Horizons. MERLOT Journal of Online Learning and Teaching, 11(2), 309-319.

Owen, E. A., Razali, A. B., Samad, A. A., \& Noordin, N. (2019). Enhancing Libyan students' english speaking performance through language game and information gap activities. Problems of Education in the 21st Century, 77(1), 110-125. https://doi.org/10.33225/PEC/19.77.110

Pinandhita, F. (2013). The Use of Hopscotch Game in Teaching Speaking to the First Grade Students of English Department of IKIP PGRI Madiun in the Academic Year of 2013/2014. English Teaching Journal: A Journal of English Literature, Language and Education, 1(2). https://doi.org/10.25273/etj.v1i2.736

Ratih, F. T., \& Ningsih, N. A. (2017). Using a board game "Snake and Lader" to teach speaking descriptive text at the eight grade students of SMPN 2 Wungu. English Teaching Journal: A Journal of English Literature, Language and Education, 5(1), 37. https://doi.org/10.25273/etj.v5i1.4726

Riandi, R., \& Suryani, L. (2018). The Effect of Using Kim's Memory Game towards Students' Speaking Skill. Journal of English Education Studies, 1(2), 99-107. https://doi.org/10.30653/005.201812.21

Sanaei, O. (2016). Investigating Anxiety Symptoms and Reactions within EFL Learners' Oral Narratives: The Case of Intermediate Level Students. Journal of Language Teaching and Research, 7(5), 902. https://doi.org/10.17507/jltr.0705.10 
Sofyan, R., Sinar, T. S., Tarigan, B., \& Zein, T. T. (2019). Using a "Snake and Ladder" Game in Teaching Speaking To Young Learners. ABDIMAS TALENTA: Jurnal Pengabdian Kepada Masyarakat, 3(2), 226-231. https://doi.org/10.32734/abdimastalenta.v3i2.4121

Taka, S. D. (2019). Teaching Speaking By Using Snake and Ladder Board Game. IDEAS: Journal on English Language Teaching and Learning, Linguistics and Literature, 7(2), 72-87. https://doi.org/10.24256/ideas.v7i2.1021

Yaikhong, K., \& Usaha, S. (2012). A measure of EFL public speaking class anxiety: Scale development and preliminary validation and reliability. English Language Teaching, 5(12), 23-35. https://doi.org/10.5539/elt.v5n12p23

Zuhri, M. D., \& Kusyairi, K. (2020). Meningkatkan Kemampuan Speaking Siswa dengan Media Board game di MTs Nahdlatun Nasyiin Kadur Pamekasan. KABILAH: Journal of Social Community, 4(2), 90-100. https://doi.org/10.35127/kbl.v4i2.3494 